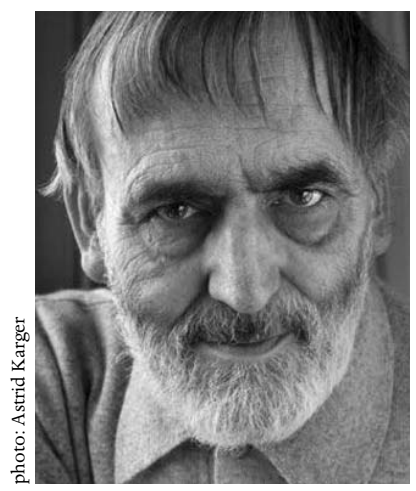

\title{
INTO THE LION'S DEN: HELMUT LACHENMANN AT 75
}

\author{
Christopher Swithinbank
}

In April 2010, the Guildhall School of Music recognized German composer Helmut Lachenmann's expertise in extended instrumental techniques, inviting him to give the keynote speech at a research day dedicated to contemporary performance practice; in May, he had a Fellowship of the Royal College of Music conferred upon him for his achievements as a composer; in June, the London Symphony Orchestra performed Lachenmann's Double (Grido II) for string orchestra, in doing so becoming the first non-BBC British orchestra to have performed his music; and in October, the Southbank Centre presented two days of Lachenmann's music including performances by the Arditti String Quartet and a much expanded London Sinfonietta, the latter broadcast on Radio 3. Outside London, Birmingham Contemporary Music Group gave a performance of his most recent work, Got Lost for soprano and piano, and the University of Manchester presented a mini-festival dedicated to his music. This roll call of events might be seen then as the celebration to be expected as a noted composer passes a milestone, ${ }^{1}$ but Lachenmann is a composer who - despite his age - could until recently have escaped such attention in Britain. In 1995, Elke Hockings wrote in these pages that, while enjoying 'an exalted reputation among a small circle of English contemporary music enthusiasts, $[\ldots]$ to the wider English music public he [Lachenmann] is little known' and critical reception has been mixed, often extremely negative. ${ }^{2}$ Introducing Lachenmann to an audience at the Southbank Centre in October, Ivan Hewett described him as 'a composer we don't know well in this country, an omission we are gradually repairing. ${ }^{3}$

Outside of festival retrospectives - at the Huddersfield Contemporary Music Festival in both 1986 and 2005, and Transcendent, a week-long festival at the Royal College of Music in 2006 - Lachenmann's music has not received much British stage time. For example, it was not until 2005 that the London Sinfonietta played any of his works. ${ }^{4}$ When it has been performed, it has evoked mixed reactions. Until the performance of Ausklang, his monumental piano concerto, at Huddersfield in 2000 (and Richard Steinitz's persistent vision seems to have played a large part in turning these views around) critics tended to damn his music as 'more concerned with musical noise than actual music [...] an apparently negative, desperately extreme preoccupation', 'better heard

\footnotetext{
${ }^{1}$ Witness the international festivities surrounding the remarkable Elliott Carter's centenary in 2008 .

2 Elke Hockings, 'Helmut Lachenmann's Concept of Rejection' in Tempo No. 193 (July 1995) 'German Issue', p. 4.

3 Author's notes from Lachenmann Weekend at the Southbank Centre, 23-24 October 2010.

${ }^{4}$ Richard Steinitz, 'The inside-out concerto' in The Guardian, 25 November 2005, Features, p. 12.

${ }^{5}$ Gerald Lamer, 'Festival' in The Guardian, 26 November 1986, p. 9.
} 
about than heard'6 or 'earnest, dreary "modern music"' - with the notable exceptions of Paul Griffiths, who found it 'difficult to remain entirely impervious to beauty's as early as a 1986 performance of Salut für Caudwell, for two guitarists, at the ICA, and David Power, who was 'struck primarily by the amazing wealth of invention' in Pression, for solo cello, that same year at the Huddersfield Festival, though Power was writing in a specialist periodical rather than the mainstream press. ${ }^{9}$

Audiences could be similarly ambivalent. Ian Pace reported 'furious reactions' to a performance of „... zwei Gefühle ... “, Musik mit Leonardo, for speaker and ensemble, at the Southbank Centre in $1994 .^{10}$ More recently, opinions have shifted. In particular, Andrew Clements and Tom Service writing in The Guardian have become advocates, but trenchant views still remain. In 2008, Robin Holloway fumed at the 'colossal self-indulgence' and 'conspicuous wastefulness' of Lachenmann's opera Das Mädchen mit den Schwefelhölzern (as seen in Madrid - the opera has, unsurprisingly, yet to arrive on British shores), describing Lachenmann as having 'inherited the Emperor's mantle of grandiose invisibility' from Karlheinz Stockhausen. ${ }^{11}$

In the academic arena, discussions of Lachenmann's music have been limited in part by the fact that the majority of his extensive writings have not been translated into English (though no doubt also due largely to the paucity of performances). A few translations are scattered in various Anglophone periodicals, including the two issues of Contemporary Music Review (xxiii/3 and xxiv/1) dedicated to Lachenmann's music, but mother-tongue German speaker Elke Hockings's lucid introduction to certain aspects of his writings in this journal remains the only article to engage with the evolution of his aesthetic thought. ${ }^{12}$ Similarly, increasingly sophisticated dialogues with Lachenmann's writings by German-speaking commentators have tended to be beyond the scope of most Anglophone discussion. Meanwhile, Ian Pace's fairly comprehensive, two-part overview of Lachenmann's oeuvre in The Musical Times represents the only attempt to offer a summary of the composer's musical development. ${ }^{13}$

The publication in 1996 of the majority of Lachenmann's writings in Musik als existentielle Erfahrung [Music as existential experience] permitted German-speaking commentators to refresh their discussions of Lachenmann's music through the prism of his aesthetic thought, but has also sparked the realization that the musicologist must tread carefully when it comes to a composer's writings, especially those tending towards the self-analytical. In the preface to a collection of essays whose publication coincided with Lachenmann's 70th birthday, Jörn Peter Hiekel and Siegried Mauser called for a widening of perspectives beyond the - somewhat naïve - tendency to write in a way such that 'most of what was stated about the composer was little more than an extended paraphrase of the composer's own ideas. ${ }^{14}$ This is a problem arising

${ }^{6}$ David Murray, 'Arts: Review of Arditti Quartet at Union Chapel' in Financial Times, 1 July 1988 , p. 21.

7 Andrew Porter, 'White heat under low light justifies the title' in The Observer, 1 August 1993, p. 49.

8 Paul Griffiths, 'Review of "Helmut Lachenmann" at the ICA' in The Times, 8 July 1986.

9 David Power, 'Huddersfield 1986' in Tempo No. 160 (March 1987), pp. 53-54.

${ }^{10}$ Ian Pace, 'Positive or Negative' in The Musical Times, cxxxix/1859 (Jan. 1998), p. 9.

${ }^{11}$ Robin Holloway, 'Whisper or Scream' in The Spectator, 28 June 2008, pp. 57-58.

12 Elke Hockings, 'Helmut Lachenmann's Concept of Rejection' in Tempo No. 193 (July 1995) 'German Issue', pp. 4-14.

${ }^{13}$ Ian Pace, 'Positive or Negative' in The Musical Times, cxxxix/1859 (Jan., 1998), pp. 9-17, and cxxxix/1860 (Feb., 1998), pp. 4-15.

${ }^{14}$ Jörn Peter Hiekel and Siegfried Mauser (eds.), Nachgedachte Musik: Studien zum Werk Helmut Lachenmanns (Saarbrücken: Pfau, 2005), p. 7. 
more frequently as composers accompany their music with words offering a definition of the musical content; this guide to interpretation 'appears as authentic and apparently arrives from the same mysterious creative world [as the music]' and so is all too often accepted without much further thought. ${ }^{15}$ However, caution is crucial. Despite feeling the need to put his aesthetic thought down on paper, Lachenmann himself is wary that anything he says is 'the debris of sense and feelings' and that much of his own writing has fallen victim to 'the silly perception that the verbal medium is more coherent than the aesthetic'. ${ }^{16}$

If one combines these universal interpretative dangers with the difficulties of translating for Anglophone audiences the philosophicalaesthetic debates that have been part of Germanic musical life since the 18th century, it should perhaps come as no surprise to find that Lachenmann's musical and verbal outputs have become tangled - not to mention that his aesthetic theories have continued to develop in concert with his music, a fact not so easily discerned from those of his essays available in translation. Lachenmann has written extensively on music in a tradition that does not shy away from drastic aesthetic conclusions, a tradition whose 'dialectic rhetoric has seldom been attractive to English-speaking music enthusiasts. ${ }^{17}$ As Richard Steinitz put it, 'the British are healthily suspicious of art, or indeed anything, pressed into the service of ideology' and while Lachenmann's music is anything but dogmatic, his aesthetic conclusions and ensuing compositional approach were - at least initially - undeniably formed by ideology. ${ }^{18}$ In continental Europe (and especially Germany) on the other hand aesthetic writings have been used as 'merchandise' for the music, and Lachenmann's birthplace, Stuttgart, boasts a rich lineage of dialectical thinkers - including Max Horkheimer - running back to Hegel himself. ${ }^{19}$ Alex Ross's reaction to his impression of Lachenmann's writings is scathing, interpreting them as straightforward rejections of the popular that, indebted to Adorno, threaten a constricted emotional range. ${ }^{20}$ Despite this, Ross has the sense to detach his listening from his reading and concedes that Lachenmann 'is a sensitive composer who places his cries and whispers with extraordinary care and keeps the listener in a tensely riveted state. ${ }^{21}$ It seems highly likely that miscomprehension of stated goals - in Lachenmann's writings - has led to miscomprehension of the musical result, or that some criticisms of the music are founded in disagreements with Lachenmann's aesthetic theory, even when correctly understood, rather than in dislike of the musical material. That the writings might continue to repel potential audiences seems a shame; they are signposts that may inform our understanding of the music and illuminate our portrait of the man, but Lachenmann remains foremost a composer, not a philosopher or aesthetician. We should hear his music and read his writings in that context. As he has observed - perhaps surprisingly given his verbal output - 'The composer has nothing to say; he has something to create. ${ }^{22}$

\footnotetext{
15 Reinhold Brinkmann, 'Der Autor als sein Exeget' in Nachgedachte Musik, p. 119.

${ }^{16}$ Helmut Lachenmann, programme brochure Donaueschinger Musiktage 1980, 22-23, as cited in Elke Hockings, 'Helmut Lachenmann's Concept of Rejection', p. 6.

${ }^{17}$ Elke Hockings, 'Helmut Lachenmann's Concept of Rejection', p. 4.

18 Richard Steinitz, 'The inside-out concerto' in The Guardian, 25 November 2005, Features, p. 12.

19 Elke Hockings, 'Helmut Lachenmann's Concept of Rejection', p. 4.

${ }^{20}$ Alex Ross, 'Ghost Sonata: What happened to German Music?' in The New Yorker, lxxix / 5 (24 March 2003), p. 69; and Alex Ross, The Rest is Noise (New York, 2007), p. 527

${ }^{21}$ Alex Ross, The Rest is Noise, p. 527.

22 Lachenmann speaking at Musik am 13. concert of his music in Stuttgart Bad-Canstatt, $13 / 02 / 2009$, Author's notes.
} 
Helmut Lachenmann's music is rooted firmly in the juddering, fragmented language of the post-war European avant-garde. It unearths logics in eerie, unfamiliar sounds as if the surface of music has cracked open and the fragile scratching behind every note is revealed. It is a music whose every fibre is concentrated on finding beauty, often in places others may have turned their backs on in disgust. It is a music of its time, invested in the Marxist aesthetics of Theodor Adorno and Walter Benjamin, with a permanent fugitive eye on the past and an eager gaze forwards to the future, but written with an unflinching ear unswayed by dogmatic tenets and informed by acoustic reality.

Born in 1935, Lachenmann was nine years old when the Second World War came to its end. Ever the eccentric, German film director Werner Herzog (b. 1942) has spoken of the bizarre, exciting playground bomb-flattened Munich provided as 'the most beautiful environment you could ever find for children,' and Lachenmann's childhood in Stuttgart may have contained some similar experiences. ${ }^{23}$ While in Herzog's early cinema these influences surface in surreal scenes and bizarre juxtapositions often informed by actual experience, but always linked by a more traditional narrative logic, in Lachenmann destroyed and fragmented landscapes are inescapable and the newly inclusive pantheon of sounds has uncovered a different, compelling logic from that of tonality or even extended serialism. Perhaps comparable are the vast canvases of Anselm Kiefer (b. 1945) whose thick alluvial layers of grey-brown oil paint bury fields of scorched earth and distorted symbols of Christianity in near-abstract grotesquery, providing 'frontal engagements with the totems of German history,' or the action-driven sculptural landscapes constructed from beeswax, felt, rubber and wood by Joseph Beuys (b. 1921) that attempt to place the creative act at the forefront, relegating its material trace to a mere sign towards its original energy. ${ }^{24}$ Any direct parallel with the representative arts would be foolish, but there are distinct similarities in the preoccupations of artists from all fields, ranging from total rejection of to critical engagement with tradition and reflecting German society's struggle to understand, digest and move on from the horrors of Nazi rule.

While in painting or sculpture depictions of a crucifix or a trench system (or, for that matter, representation's total disintegration into abstraction) usually carry symbolic meaning and are intended to do so, music's relationship with the symbolic or with verbalized meaning of any kind is by its nature obscure. It is not possible for a purely musical work to place the actions of a civilization on trial, as is arguably possible in representative art and undeniably possible in works of theatre and literature. For example, a play such as Friedrich Dürrenmatt's Der Besuch der alten Dame (1956) chillingly dramatizes the extent to which apparently good societies can be corrupted until previously amicable neighbours turn on each other. Nonetheless, it may be possible for music to engage with its social hierarchies in a fashion that challenges the status quo.

Perhaps some of the most important experiences for Lachenmann as a young musician were his visits to the Darmstadt Internationale Ferienkurse für Neue Musik and his contact there with the personalities that made up the avant-garde of the 1950 s - a truly international pantheon of potential influences. Among the figures such as Karlheinz

\footnotetext{
${ }^{23}$ Herzog speaking in Imagine ... Werner Herzog: Beyond Reason, BBC, 2008.

${ }^{24}$ Simon Schama, 'Trouble in Paradise' in The Guardian, 20 January 2007, Review Section, p.12.
} 
Stockhausen, Bruno Maderna, Henri Pousseur and Theodor Adorno, whom Lachenmann met or heard speak at the 1957 Summer Course, none had as large an impact as Luigi Nono. ${ }^{25}$ Having seen him speak about the development of serialism at Darmstadt and then heard his Varianti at the 1957 Donaueschinger Musiktage, Lachenmann travelled to Venice between 1958 and 1960, where he lived and studied with Nono, who became not only his teacher but a life-long friend as well. ${ }^{26}$ From Nono, Lachenmann developed the belief that music had a social function, becoming so familiar with Nono's music and thought that he acted as ghostwriter for two lectures Nono gave at Darmstadt and produced the official piano reduction of Nono's opera Intolleranza $1960 .{ }^{27}$

In one of his earliest published essays, 'Luigi Nono oder Rückblick auf die serielle Musik', Lachenmann speaks about the difficulty a composer faces, as he is forced to rely on the institutions that make up the society that he would change. ${ }^{28}$ The core question for any contemporary composer is: 'How do I free the technical-compositional material from the mistaken interpretations that have been established by society, so that I can reach a situation in which I can freely and critically engage with this society as a creative artist? ${ }^{29}$ This urge to engage in some way with society is clearly fundamental to Lachenmann's early conception of artistic activity, in line with Marxist literary theorist Christopher Caudwell's idea of literature as 'functioning to increase man's freedom. ${ }^{30}$ In this paradigm, society is a process, which an artist can either embrace or reject and, following Marxist dialectic, the latter is the only route to change (in this worldview: progress). ${ }^{31}$ This attempt at a rejection of or reaction against social mores through music seems symptomatic of a need to avoid 'thoughtless conventionality' that has strong historical roots in the artistic and philosophical aftermath of World War II. But while historical roots are certainly part of this attitude to creativity and the artistic impulse, they often cannot explain the stylistic mode an individual chooses. ${ }^{32}$ Despite a theoretically similar position on the political and historical spectra, Hans Werner Henze attacked Lachenmann as a 'representative of musica negativa' fixated on the ugly and the broken, demonstrating how political-historical affinities do not necessarily lead to aesthetic similarities. ${ }^{33}$

${ }^{25}$ Wolfgang Thein, 'Lachenmann, Helmut Friedrich' in Die Musik in Geschichte und Gegenwart: allgemeine Enzyklopädie der Musik ed. Ludwig Finscher (Kassell \& Stuttgart: Bärenreiter \& Metzler, 2003), p. 968.

${ }^{26}$ Rainer Nonnenmann, "Wenn ich nicht dich gefunden hätte...": Helmut Lachenmann als Schüler Luigi Nonos' in Neue Zeitschrift für Musik: Das Magazin für neue Töne, clxvii/1 (Mainz: Schott, Jan.-Feb., 2006), p. 26.

${ }^{27}$ Rainer Nonnenmann, "Wenn ich nicht dich gefunden hätte...": Helmut Lachenmann als Schüler Luigi Nonos', p. 27

${ }^{28}$ Helmut Lachenmann, 'Luigi Nono oder Rückblick auf die serielle Musik' in Musik als existentielle Erfahrung, Wiesbaden (Breitkopf \& Härtel), 2004, p. 247. [Originally a radio programme broadcast in 1969.]

29 Helmut Lachenmann, 'Luigi Nono oder Rückblick auf die serielle Musik', p. 248.

${ }^{30}$ David N. Margolies, The Function of Literature: A Study of Christopher Caudwell's Aesthetics (London, 1969), p. 11

${ }^{31}$ It should be noted however that Lachenmann's erstwhile Marxism was not as straightforward as that of Nono. In 1993, he even stated 'je n'étais pas marxiste' [I was not Marxist], in an interview with Peter Szendy, 'Des paradis éphémères', programme booklet for Le Festival d'Automne à Paris 1993, p. 5.

${ }^{32}$ Helmut Lachenmann, 'Luigi Nono oder Rückblick auf die serielle Musik', p. 247.

${ }^{33}$ Hans Werner Henze, Die englische Katze, p. 345. The conflict with Henze is well documented and Lachenmann's 1983 response has been translated into English by Jeffrey Stadelman - and accompanied by other evidence from the dispute - as 'Open Letter to Hans Werner Henze', Perspectives of New Music, xxxv/2 (Summer 1997), p. 189ff. In May 2010, Henze and Lachenmann met for the first time in 30 years at the Royal College of Music in London, spoke and reconciled their differences. 
In the wake of World War II, the prevailing, articulated wish at international events such as the summer courses in Darmstadt and the festivals in Donaueschingen, was to move away from traditional categories of aesthetic value. Adorno's much quoted statement, 'to write poetry after Auschwitz is barbaric', may be an extreme voicing of this critical loss of faith in the structures of humanist society, and Adorno was certainly more polemical than most, but it nonetheless shows the depth of feeling running through the artistic and, in particular, the musical community at this time. ${ }^{34}$ The extremity of this reaction has since been heavily criticized, but it is valuable to remember the personal feelings that engendered advocacy for an aesthetic sea change. Speaking in 2010, Lachenmann recalled hearing the radio playing Beethoven's Ninth Symphony to accompany announcements about soldiers' deaths at Stalingrad and 'Siegfrieds Tod' from Götterdämmerung to mourn Hitler's death, 'like a magic to paralyse brains'.$^{35}$ Given the strength of these personal associations, it is perhaps no wonder that artists of all persuasions felt it necessary to distance themselves from traditions apparently inextricably tangled in the wreckage of Nazism.

Once they had had time to glance back on their actions, leaders of the revolution like Pierre Boulez were able glibly to summarize their attitudes with pithy comments about blowing up opera houses, but such throwaway remarks belie the complexity in the budding avant-garde's relationship with tradition. ${ }^{36}$ The obvious link between the post-war avant-garde and older music lies in the extension of the serial techniques developed by the Second Viennese School pre-WWII, but there are also links in the attempts at textural and performance-technical innovation. The ghostly streaming of chromatic sul ponticello lines, clouds of pizzicati and skeletal rattling of ricochet bowing in the Allegro misterioso of Alban Berg's Lyric Suite hint at many later developments, not least the hushed, shadowy pitches of Helmut Lachenmann's Second String Quartet.

However, where the Second Viennese School had referred to the classical tradition by writing for established instrumentations and genres to establish their credentials (potentially under scrutiny due to their radical atonality) and viewed themselves as an inevitable development of the tradition of Wagner and Brahms, the post-war avant-garde were far more interested in promoting themselves as a fresh start. ${ }^{37}$ In the late 1940s the works performed at the Darmstadt Summer Courses shifted rapidly from 'titles such as Sonatine, Suite for Piano, Chamber Symphony, Scherzo, and Concerto in E Flat' to "Music in Two Dimensions," "Schipot," "Polyphonie X," "Syntaxis," "Anepigraphe" [...] "Perspectives," "Structures," "Quantities," "Configurations," "Interpolations"'. ${ }^{38}$ These abstractions - worthy of a science fiction film or an electronics manual - went hand in hand with radical rethinkings of traditional means of sound production. In works such as Luciano Berio's Formazioni and Karlheinz Stockhausen's Gruppen, the spatial possibilities of the orchestra were explored by rearranging the standard on-stage orchestral layout (in the former) or breaking the orchestra

\footnotetext{
34 Theodor W. Adorno, trans. Samuel \& Shierry Weber, Prisms (Cambridge, Mass., 1981), p. 34. [German original published 1955.]

35 Lachenmann speaking at the Southbank Centre, 23 October 2010, author's notes.

36 Pierre Boulez, 'Sprengt die Opernhäuser in die Luft!' in Der Spiegel, 1967 No. 40 (25 September), p. 166.

${ }^{37}$ Douglas Jarman, ed., The Twentieth-Century String Quartet (Todmorden, 2002), p. 13.

38 Alex Ross, The Rest is Noise, p. 392.
} 
up into three separately-conducted groups placed around the audience (in the latter), while unconventional playing techniques or instruments became increasingly common. Lachenmann's Kontrakadenz (1971) is a 20-minute orchestral work that looks at home in this landscape. In addition to a standard symphony orchestra including six percussionists, the score calls for four 'ad-hoc players' whose armoury of sound sources includes ping-pong balls (and a suitable surface for bouncing), radios, scrap metal, coins, zinc tubs of water (for sloshing), polystyrene (for rubbing together) and several more conventional items. Much of the wind section also requires recorder heads to produce piercing whistling sounds and there is more polystyrene distributed about the orchestra, not to mention a Hammond organ, an electric guitar and a tape part, which seem relatively tame in comparison. ${ }^{39}$ The use of a recorded announcement mid-piece informing the audience that they are listening to 'Kontrakadenz by Helmut Lachenmann performed by ...' is also of its time, provoking comparisons with similar self-reference in Berio's Sinfonia (1968), for example..$^{40}$

There is a risk that this bestiary of unusual rasps, rattles, shrieks and pops might seem ludicrous, the product of a junkyard rather than an orchestra. This risk is dealt with consummately on an auditory level in Kontrakadenz: the sounds add up to a convincing musical discourse - the sudden stillness filled only with the lapping of water (b. 236) affectingly lives up to musique concrète's appropriation of the connotations we attach to specific sounds, and bouncing ping-pong balls join gettato bowing and other percussive rattlings in coherent textures (e.g. bb. 22-26). In his programme note to temA (1968), for flute, voice and cello, Lachenmann writes of wanting to avoid his use of unfamiliar sounds and techniques being 'tolerated as humorous, Dadaist or expressionist elements'. The shock should instead derive from these elements' integration into the work's fabric, rendering them serious rather than amusing. ${ }^{41}$

This structuralist approach in some ways points up Lachenmann's traditionalism: he is a composer deeply concerned with form, process and coherent experience and feels his roots lie deep in the canon. A key period of Lachenmann's early output, roughly spanning 1968-1980 (beginning with temA), he self-defines as being characterized by 'rigidly constructed denial'. ${ }^{42}$ This denial is the refusal to submit to the listening habits that Lachenmann believed become habituated in the structures of society and therefore require dialectical opposition. However, this is not a cruel tendency towards alienated grotesquery, but an honest wish to provoke a questioning of habit and convention. In an introductory text to Pression (1970), he wrote of his music offering the audience a chance 'to listen differently and to make them aware of and test their listening habits and the aesthetic taboos these hide through a distinctive provocation' ${ }^{43}$ So Pression, a study for solo cello, rarely uses the conventional sound of the instrument, instead choosing to examine every other physical relationship between the player's hands, the bow, the strings and the instrument body. Sounds are linked in a highly rational fashion not by their acoustic attributes, but instead by the physical actions which cause them. Lachenmann viewed this as illuminating his perception that: 'In the case of the beautiful, professional cello tone, the relationship of

\footnotetext{
${ }^{39}$ Helmut Lachenmann, Kontrakadenz, für grosses Orchester (Wiesbaden: Breitkopf \& Härtel, 1982), iv-v (Instrumentation and Instructions).

40 Helmut Lachenmann, Kontrakadenz, bb. 187-189.

${ }^{41}$ Helmut Lachenmann, 'Einführungstext zu "temA”' in Musik als existentielle Erfahrung, (Wiesbaden: Breitkopf \& Härtel, 2004), p. 378.

${ }^{42}$ Helmut Lachenmann, 'Selbstportrait 1975' in Musik als existentielle Erfahrung, p. 154.

${ }^{43}$ Helmut Lachenmann, 'Einführungstext zu „Pression”' in Musik als existentielle Erfahrung, p. 381.
} 
action and result is - as with all sounds considered "beautiful" in our society - particularly obscured regarding effort and resistance, whereas with the extreme pressure of the fingertips sliding along the wood of the bow the relationship is much more complicated: an almost inaudible result speaks, as it were, of a maximum effort. ${ }^{44}$

In attempting to escape an 'invisible prison' of tradition, Lachenmann sought to reject all sounds already categorized as beautiful by using a palette of new instrumental techniques, combinations of sound, sound sources and (to a lesser extent) electronics. ${ }^{45}$ However, the rejection of traditional methods of sound production during this phase of Lachenmann's output is not the type of 90-degree aesthetic break that John Cage espoused with his desire to create music 'free of individual taste and memory (psychology) and also [free] of the literature and "traditions" of art' ${ }^{46}$ Despite its role as an 'invisible prison', tradition is embodied for Lachenmann by works that 'form those historical examples and artistic experiences that attempts at breaking out of this prison can invoke, if they require justification at all' ${ }^{47} \mathrm{In}$ his writings and public appearances Lachenmann again and again references Beethoven and Mahler in particular. His 1976 work for solo clarinet and orchestra, Accanto, makes use of a recording of Mozart's Clarinet Concerto to form $\mathrm{a}$ - for the most part unheard - framework. Iyad Mohammad describes Lachenmann as having 'crucified it [Mozart's Clarinet Concerto] in order to resurrect it, to bring it back to life. He sacrificed it for the sake of revealing to us its true value'. ${ }^{48}$ While rejecting traditional soundproduction techniques, Lachenmann remains embedded within the tradition by continuing to write for orchestras, string quartets, pianos, clarinets and even, perhaps the most reactionary of all, opera houses. It is precisely the situations with the longest and richest traditions that he seeks out and seeks to renew through subversion.

Lachenmann's concept of rejection has probably been the element of his aesthetic thought most often recycled and regurgitated by commentators, but he has increasingly moved away from it since the 1980s. ${ }^{49}$ His three string quartets, written in 1972, 1989 and 2001 respectively, demonstrate very clearly his shifting approaches and interests from an early implementation of 'musique concrète instrumentale' to a later, increasingly inclusive aesthetic that no longer rejects traditional playing methods as a matter of course. The First String Quartet, Gran Torso, presents a soundscape of creaks, cracks and finely differentiated, pitchless bowing on various parts of the instruments. An extreme instance of rejecting traditional sound production, Gran Torso provides a powerful example of the structural potential of new sound possibilities, leading audiences into an intense central passage of near-silence articulated by a slow-breathing 'cadenza' on the tailpiece of the viola. Before the première of his Second String Quartet Reigen seliger Geister, Lachenmann stated that 'since the issue is not about new sounds but about new ways of listening, this must also be possible with the "beautiful tone" of a cello string,' and consequently we find a work whose material no longer comes exclusively from the realm of extreme extended techniques. ${ }^{50}$

\footnotetext{
${ }^{44}$ Ibid.

${ }^{45}$ Helmut Lachenmann, 'Über Tradition' in Musik als existentielle Erfahrung, p. 339.

${ }^{46}$ John Cage, Silence: Lectures and Writings by John Cage (Middletown, CT, 1973: first published 1961), p. 59

47 Helmut Lachenmann, 'Über Tradition', p. 339.

${ }^{48}$ Iyad Mohammad, 'What Has Lachenmann Done With My Mozart?! A Note on Whatever Is Recorded on the Tape in Accanto' in Contemporary Music Review, xxiii/3 (2004), p. 146.

${ }^{49}$ Elke Hockings, 'Helmut Lachenmann's Concept of Rejection', p. 7.

${ }^{50}$ Heinz-Klaus Metzger and Helmut Lachenmann, 'Fragen - Antworten' in Helmut Lachenmann, Musik als existentielle Erfahrung, p. 194.
} 
Nonetheless, Reigen seliger Geister does not entirely disavow the sound world established by its predecessor, making heavy use of half-stopped flautato to produce a shadowy, veiled pitch that he describes as 'sphärisch' [of the spheres] and continuing to use scratch-tones, though to a lesser extent. A further 12 years later with Lachenmann's Third String Quartet, Grido, we find a work whose focus on pitch inflections and gestures has almost completely supplanted the earlier interest in building structure from timbral processes. This is the case to such an extent that it was possible for him to produce Double (Grido II) for string orchestra, a transcription of the string quartet with very minimal structural alterations. The previous two quartets rely so specifically on the timbre and energetic situation of a quartet of solo strings that it would be impossible to attempt to translate these works for a larger ensemble. The Third String Quartet's characteristic sounds are high, clear, wailing harmonics - fields of pitch throbbing with quarter-tone dissonances reminiscent of Giacinto Scelsi. Unlike its predecessors, the strings are left tuned in fifths and Grido is truly loud, filled with fortissimos and sharp punctuations of the texture. One reviewer joked that 'even Helmut Lachenmann has gone soft with old age', ${ }^{51}$ while Paul Griffiths recognized the completion of 'a development toward more normal sounds'. ${ }^{52}$

In May 2004, Lachenmann was awarded the Royal Philharmonic Society Music Award for Chamber-Scale Composition for Grido. He had received prizes before: in the 1960s he was awarded prizes by the cities of Munich and Stuttgart and in 1997 received the prestigious Ernst von Siemens Foundation Music Prize, but this was the first time he had ever been honoured in Britain. It is possible that this award is simply a reflection of a jury's appreciation for Lachenmann's use of more familiar material - the flickering gestures, pulsating tremolandi and scurrying scales of Grido may recall the stormy excitement of a wild Shostakovich fugue, and the humorous lightness of the final dyad (a major third, no less) seem surprisingly reminiscent of the wit of Haydn - but more than anything the award seems a reflection of a wider acceptance of his music.

His most recent work, Got Lost, is a half-hour duet for soprano and piano that combines the extended techniques from earlier works such as striking the frame of the piano with a hammer or the soprano spitting out isolated syllables, with full-bodied operatic singing and extensive, Lisztian runs on the keyboard. The use of the voice is perhaps the most surprising element, given the more or less total absence of the traditional operatic mode from Lachenmann's opera, completed in 1996, but its 2010 performance in Birmingham was received as 'a tour de force's3 and heard as confirmation of Lachenmann's 'musicality, his sense of rhythmic immediacy allied to broad dramatic pacing, his imaginative grasp of the theatre of performance, and not least his sheer wit'. ${ }^{54}$ In fact, these reactions are perhaps over-enthusiastic. Ivan Hewett's perception of Got Lost at its British première in Aldeburgh as 'vastly impressive but [... over-extended' seems a more plausible evaluation, but it speaks volumes that other reviewers didn't turn to what

${ }^{51}$ Ulrich Pollmann, 'Aber bitte nicht schwätzen!' in Der Tagesspiegel, 30 April 2003.

52 Paul Griffiths, 'Critic's Notebook; Little Girl's Suffering Becomes A Big Opera', The New York Times, 2 September 2002.

53 Andrew Clements, 'Leonard/Hind/BCMG - review' in The Guardian, 13 October 2010, p. 36 .

54 David Fanning, 'Birmingham Contemporary Music Group, CBSO Centre, Birmingham, review' in The Daily Telegraph, 12 October 2010. 
would once have been a knee-jerk reaction of dismissal. ${ }^{55}$ Elsewhere last autumn, Lachenmann was described as having moved 'from awkwardsquad to senior composer, ${ }^{56}$ while the weekend of performances at the South Bank Centre was described as 'cementing his reputation as a true original. ${ }^{57}$

Is the change in critical reception over the last 30 years due to changing listening habits or a change in Lachenmann's music? It seems most likely that it has taken time for his music to become integrated into our aural landscape. Yes, more recent compositions do take a less extreme approach to some extent, but major, uncompromising works from the 1970s and 80s such as Gran Torso or Ausklang continue to excite audiences with the astonishing wealth of expression they offer. Perhaps the way has even been cleared by composers employing various extended techniques 'as humorous, Dadaist or expressionist elements', allowing audiences to become familiar with and hear the structural behaviour of those sounds. Whatever it is that has changed opinions, what one must hope for in the coming years is that it doesn't continue to require a milestone such as a 75 th birthday for this music to be programmed. Lachenmann writes, 'hearing, no different from composition itself a form of human seeking, is, either way, certainly a flight: as flight into the interior of the damaged ego but a flight directly into the lion's den. And therein lies probably the only way out. ${ }^{, 58}$ If music is to touch us, we must face the full fury of the demons of tradition and to do so we require great composers. Lachenmann is one.

\footnotetext{
${ }^{55}$ Ivan Hewett, 'Mahler Chamber Orchestra/Aimard at the Aldeburgh Festival' in The Daily Telegraph, 29 June 2009. He reiterated this opinion in a review of Got Lost's performance at the Southbank Lachenmann Weekend, 'Lachenmann Focus, Southbank Centre, review' in The Daily Telegraph, 25 October 2010.

${ }_{56}$ Philip Clark, 'From awkward-squad to senior composer' in Gramophone, 18 October 2010.

57 Andrew Green, 'Free radical' in Classical Music, 9 October 2010, p. 26.

${ }^{58}$ Helmut Lachenmann, 'Musik als Flucht in die Höhle des Löwen' in Meinrad Walter (ed.), Ein Hauch der Gottheit ist Musik. Gedanken grosser Musiker (Düsseldorf: Patmos, 2006), p. 65.
} 


\section{Helmut Lachenmann}
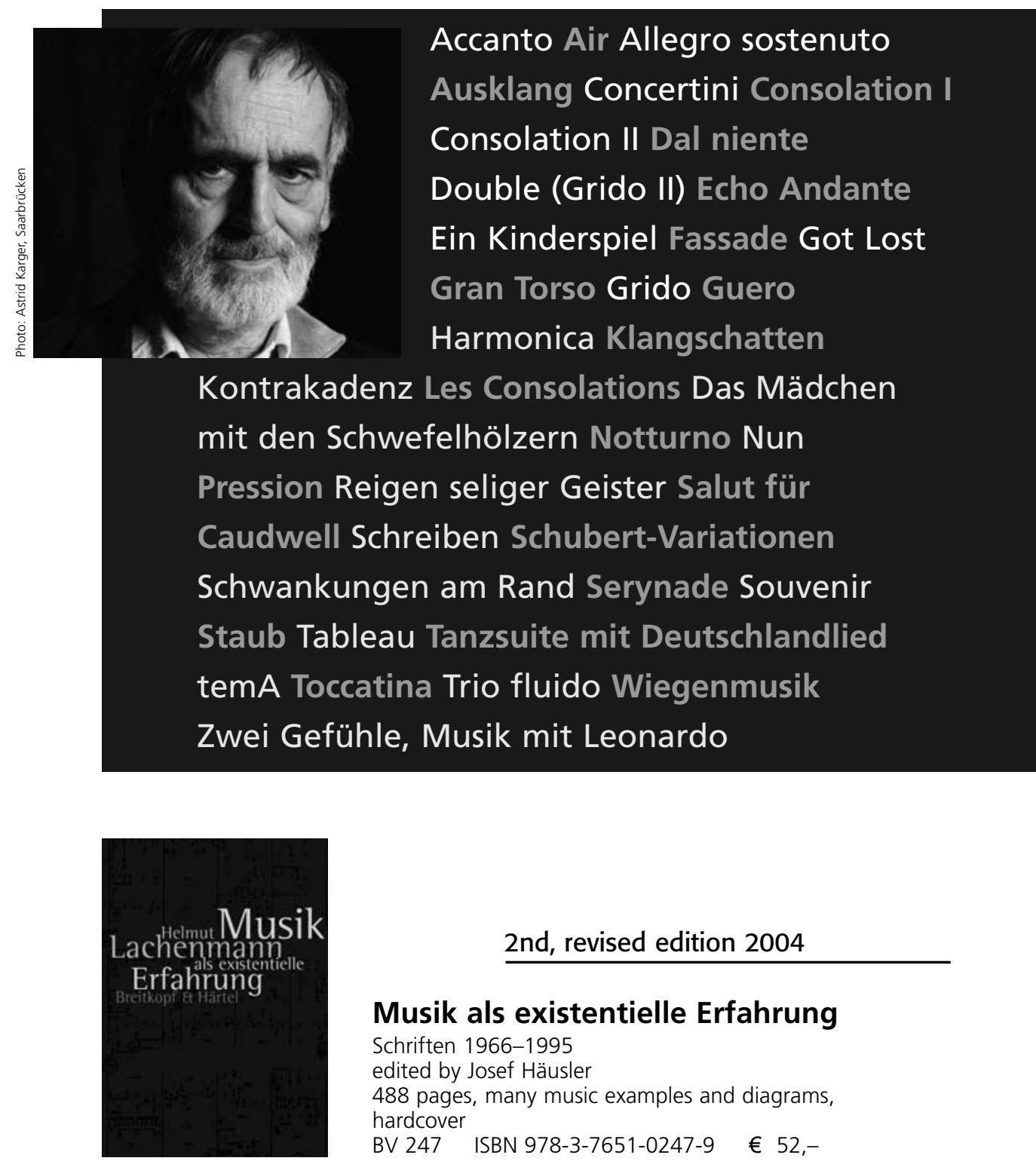

2nd, revised edition 2004

Musik als existentielle Erfahrung

Schriften 1966-1995

edited by Josef Häusler

488 pages, many music examples and diagrams, hardcover

BV 247 ISBN 978-3-7651-0247-9 € 52,-

further information:

www.breitkopf.com/Contemporary Music/

Helmut Lachenmann

with texts, audio files and more ... 